\title{
The Hospital of Santa Maria della Scala, Siena, 1090-1990
}

\author{
J H Baron
}

Hospital centenaries are so common that the $B M \mathcal{F}$ rarely allots them more than a sentence or two on Minerva's page. But when a hospital has flourished on the same site for a thousand years ${ }^{1-3}$; when its organisation, function, structure, and beauty were once an ideal European model; and when it has remarkable murals of late mediaeval charitable and medical life, ${ }^{124}$ then some celebratory article seems indicated, particularly because the hospital transfers this year to new buildings.

\section{History}

Anyone coming out of the cathedral at Siena walks down a flight of steps; these scala are the origin of the name of the church and hospital across the square. The hospital seal shows the Virgin and child, and in her right hand are steps (the ladder to heaven) surmounted by a cross. By legend the hospital was founded in 898 by a poor cobbler, Sorore, but the first document as xenodochium et hospitalis is of 29 March 1090, making Santa Maria della Scala one of the oldest surviving hospitals of the world.

It was at first a "hostel and hospital" for pilgrims and travellers because Siena lay on the main road from north Europe through northern Italy to Rome. Although the hospital was probably founded by the canons of the cathedral, it was run by friars and lay brothers and sisters, who in the fifteenth century may have fabricated the legend of its foundation by a layman, not a priest. The increasing numbers of lay hospital staff and their success led to conflict with the cathedral clerics as to who should control the wealthiest organisation in Siena. It needed a papal bull by Celestine III in 1193 to remove the hospital from the jurisdiction of the cathedral and to make it an independent lay organisation that could and did think

BrMed f 1990;301:1449-51

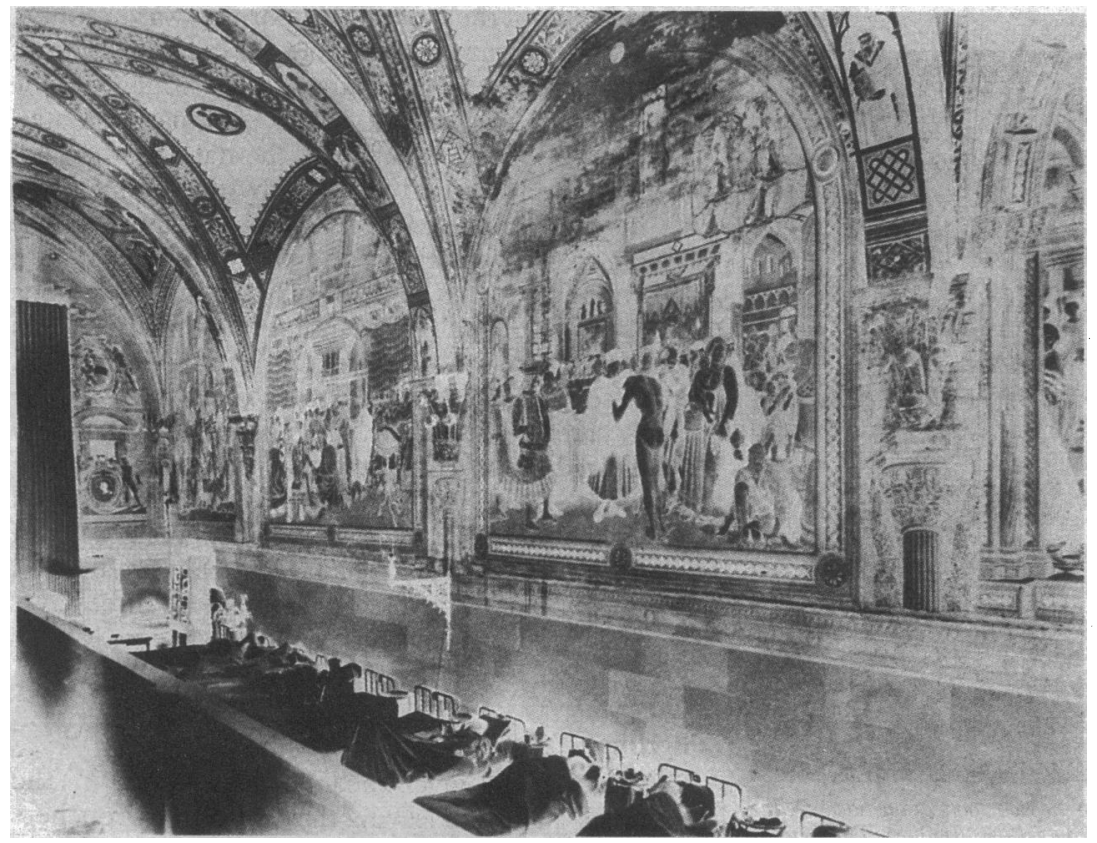

FIG 1-The pilgrim hall, with walls by Agostino di Marsiglio and murals by Domenico di Bartolo, was a ward until 1983 nothing of appealing to the Emperor or the Pope if thwarted by city or church authorities.

The statutes of $1305,{ }^{5}$ written by the Augustinian Blessed Agostino Novello, describe a powerful autonomous organisation within the city and state of Siena owning much land, granaries, and other smaller hospitals. These statutes were soon used as a model by the Emperor Sigismund - and in 1401 by the Duke of Milan - for hospitals in their territories. Finance came from bequests and donations of money, houses, and land, especially from the many wealthy Sienese bankers and merchants who bequeathed their perhaps ill gotten gains to the hospital in the hope of saving their immortal souls. The hospital was run by lay brothers who seemed to have been God fearing, honest, and efficient. The head of the hospital was the rector, usually a rich merchant or banker, who on appointment bequeathed all his possessions to the hospital. The first rector was said to be Beringario in 1200, and the last Attilio di Antonio Riniero di Rocchi from 1855 to $1861 .^{6}$

Because of the size and importance of the hospital, the Sienese republic soon insisted on the power of veto on the nomination of the rector, and in 1404 the council of the republic took over the nomination itself, so that the rector became a city officer and councillor. In 1433 a city ordinance boasted that the hospital "gives great honour to our city, and in past time enjoyed good and great fame among all Christian nations," and St Bernadino praised the hospital as one of the two eyes of the city: in reality there were constant squabbles for authority within the hospital and the city.

Santa Maria della Scala cared for four different groups: foundlings, the old and poor, the sick, and pilgrims.

\section{Foundlings}

Cast off (gittati) or little cast off (gittatelli) babies were mostly abandoned on the steps of the hospital; others were pushed through a turnstile at its entrance or sent in from surrounding villages. In 1298 there were more than 300 boys and girls in care. Foundlings were immediately given to wetnurses in a special building; they were later weaned, educated, and given a trade, the profits of which were kept in a special account in the hospital. Some foundlings were assigned to foster parents in the city, but only after satisfactory inquiries into their socioeconomic state. The foundlings were brought back into the hospital at age 5 and kept together until they were 8 , when the boys were separated off for schooling and to learn a trade while the girls stayed with the lay sisters for domestic work and weaving.

At age 18, those foundlings who wanted to leave had to be given all their earnings over the years plus 100 soldi, a set of clothing, and household furnishings. Girls who left were given a dowry of 50 lire either to enter a convent or to marry, in which case the husband had to invest part of the dowry in immovable property.

The hospital kept careful records about the time and location of the deposit of the baby, together with any special marks or objects, such as a necklace of half a coin or medallion, by which the foundling might be 
eventually recognised and reclaimed by the original parents even years later.

We know that in 1618 there were 1212 foundlings, of whom 367 were in the hospital and 845 in the country with wetnurses. In the 20 years $1755-74$, 5702 foundlings were admitted, of whom 3718 (74\%) died.

\section{The poor and the elderly}

Alms were given three times a week, with a double portion for pregnant women. The 1305 statutes required that "One of the brothers of the hospital be appointed giver and dispenser of the alms of loaves ... to the degraded poor of the city. .... Also we decree and ordain that of the poor of the masses who inhabit the city and county of Siena, they, who are of good family and descent, and are brought to the hospital ... . shall have . . . a servant to make ready their beds and dainty

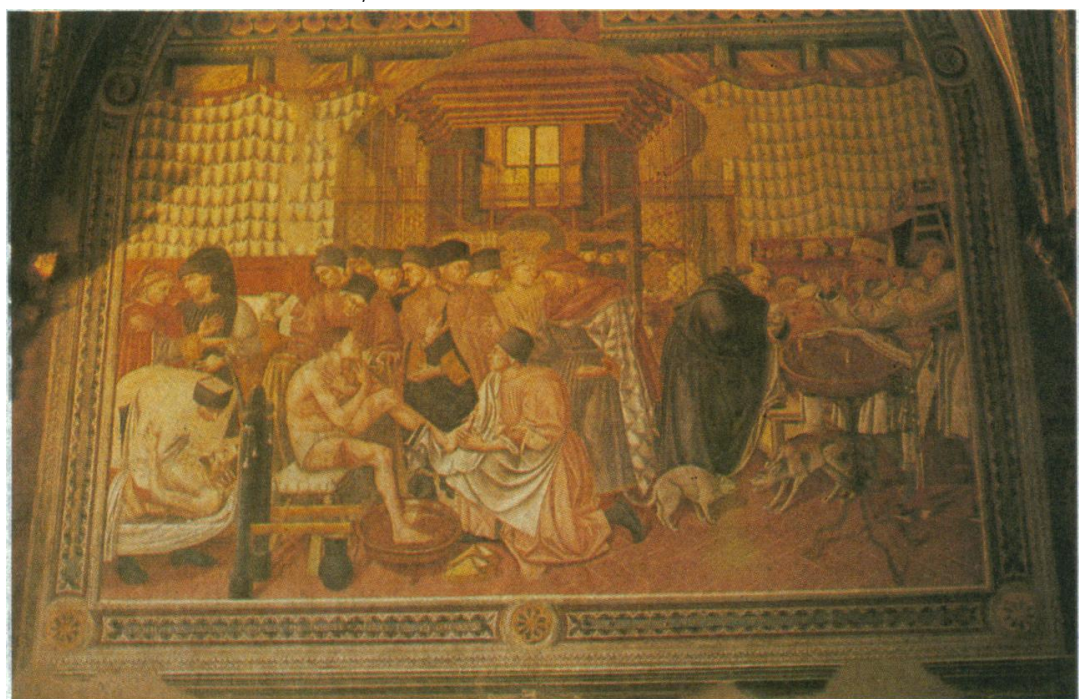

FIG 2- "Patient Care" (Cura e governo degli infermi; 1440-1). Looking at right angles to the main ward through to a second pilgrimage hall, at the side of which was the patients' kitchen; in the background a servant is carrying a tray. The coat of arms is that of Carlo d'Angelino Bartoli, rector from 1410 to 1427. The hospital surgeon, Bartolo di Tura Bandini, is examining a young man sitting on a bench with a gaping wound in his right thigh; his feet are being washed in a basin, at the side of which is a jug, and his slippers stand waiting on the tiled floor. On the left a patient is being lifted caringly up on to a stretcher, with a sheet tied to the bedpost, and his urine is being examined. On the right a friar takes a confession from a dying man, aboe whose head on a shelf are bread, a pomegranate, a carafe of water with an inverted glass, and boxes. above whose head on a shelf are bread, a pomegranate, a carafe of water with an inverted glass, and boxes. foreground a quarelling cat and dog symbolise the eternal dispute of physician and surgeon

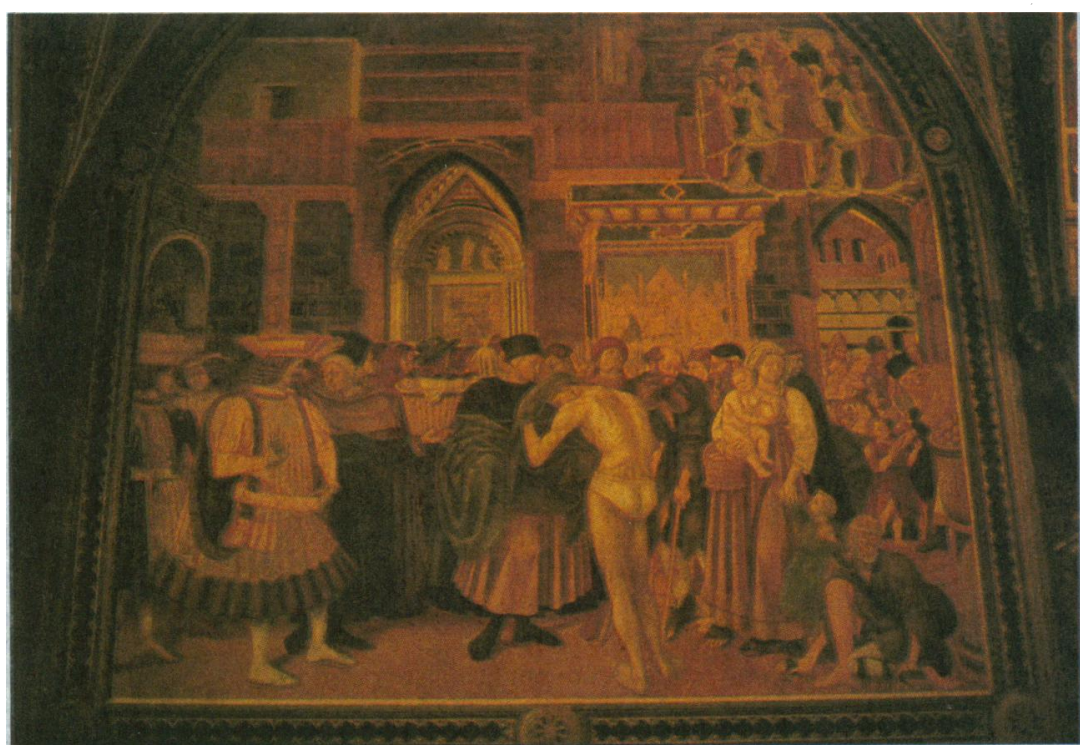

FIG 3- "Almsgiving" (Distribuzione delle elemosine; 1441). Seen through the two doors at the back are the main doors of the cathedral, with its now lost lunette, as well as the wall of the Bishop's palace. The rector is doffing his hat as he shows an important visitor how the hospital clothes the naked and gives food to beggars, cripples, and pilgrims, one of whom carries a child in a basket on his back food and wait on them so that they may not suffer from neglect." On feast days the rector himself was obliged "to wait upon the poor, the sick, and the foundlings male and female, and place before them six times every year the various dishes for their meal."

\section{The sick}

A pilgrimage friar directed the nurses and arranged admissions of sick people in collaboration with the doctor. Unusual in the middle ages, one bed contained one patient only and was provided with sheets, which were changed when dirty. The beds were made of iron, rather than wood, for ease of cleaning and to discourage vermin. Patients were not only to be welcomed graciously and treated free, but also to be treated with respect, both for the privacy of the individual and with special attention to modesty: "The sick and the poor must be received with a kind and gracious spirit." Patients were given a special diet including chicken, bread, syrups, and wine and were forbidden unsuitable foods. When the bell rang the nursing friars and sisters carried the food to the male and female patients (the sexes were of course separated), and everyone had to wash their hands.

Patients were not only housed, washed, fed, and clothed, they were also treated with the aim to cure, one of the earliest examples of such a therapeutic objective. ${ }^{7}$ The hospital at its own expense employed two salaried doctors (one physician, one surgeon) and an apothecary "who will heal cheerfully and graciously."

The fourteenth century statutes were revised 200 years later by Grand Duke Ferdinando I de'Medici after the take over of Siena by Florence, and an additional surgeon was employed. The doctors together with the apothecary visited the patients in the morning, followed by the assistant doctor writing down in his notebook the treatment prescribed, especially Peruvian bark and various medicines, oils, and unguents, all prepared by the ointment maker. In the surgical hierarchy the chief supervised the deputy, who performed the most important treatments himself, and taught the students bloodletting. In the seventeenth and eighteenth centuries the hospital was unusual in insisting on hands on, practical patient care by the students and not just the book learning common at that time. There was a barber-surgeon. Assistant doctors worked in shifts from midday until dinner, and from Ave Maria until the hour of the morning ward rounds. The sanitary arrangements were the responsibility of the head nurse, whose nurses came round to the patients with wash hand basins and barley water. There was a separate sickbay for the staff.

Patients were carried in litters by the students and the hospital servants. The students assisted the surgeon in his operations, and they also helped with bleeding the patients, putting on dressings to wounds and sores, and applying cupping. Hospital servants cleaned the room, transported the patients, and supervised convalescence. Others cleaned the public places, cared for personal belongings of the patients, and showed their urine samples to the doctors. There was a formal procedure for patients and convalescents to be able to complain to the rector about their care and treatment. Patients mostly had fevers and were allowed out of hospital after having been afebrile for three days, and if necessary there was aftercare at home.

\section{Pilgrims}

Pilgrims were given board and lodging in the pilgrimage halls. On leaving they were given vouchers to be exchanged for food and drink at lodges within Sienese territory. Throughout the republic there were 


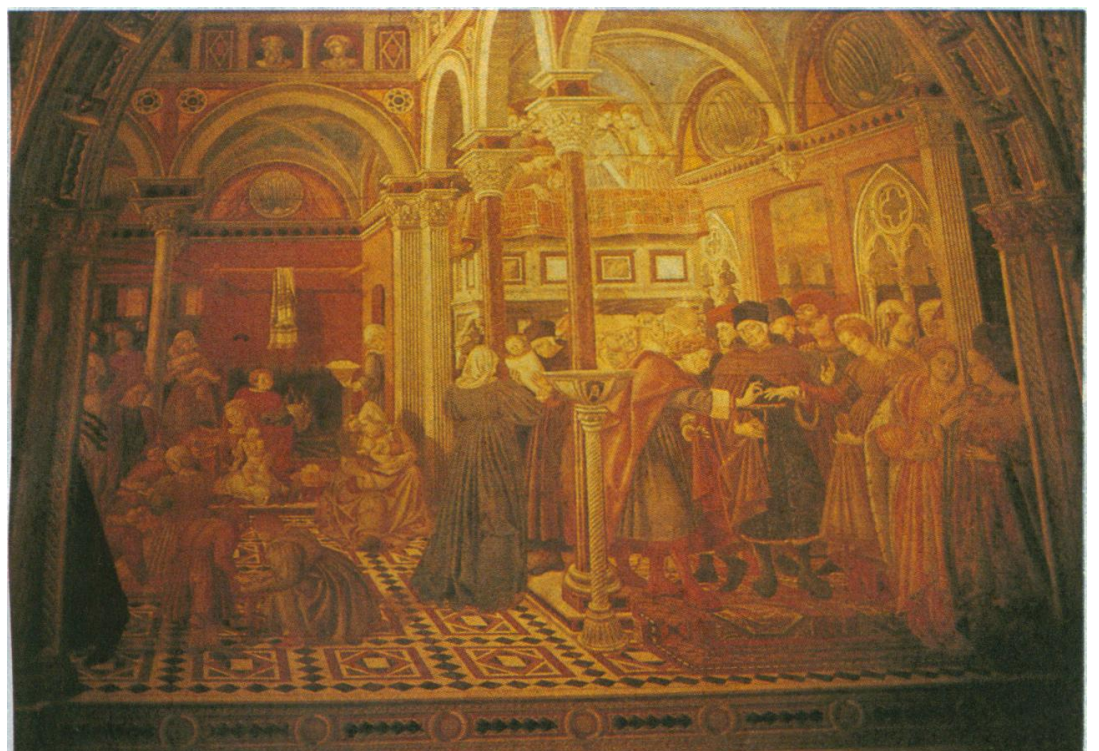

FIG 4-"Reception, Education, Growth, and Marriage of the Foundlings" (Accoglimento, educazione, crescita, e nozze dei trovatelli; 1441-2). The rector has discovered a baby deposited in the church (centre right). He hands the swaddled foundling over to the wetnurses in the hospital (left). They wash and dry the baby and put it to the breast. The children are fed, educated, and taught a trade (left foreground). A foundling marriage (on the right) is attended by well dressed ladies; nearby is a stoup bearing the ladder insignia

fortified granaries, which were stocked and restocked with food against famine. Even outside Sienese territory some 70 hospitals had similar organisational schemes for patients' aftercare.

Staff, whether paid or voluntary, were well organised for security and compensation against injury as well as for mutual help, such as being able to obtain immediate bail money if imprisoned.

\section{Frescoes}

When in 1456 Francesco Sforza $^{8}$ was planning his great hospital in Milan (eventually built by Filareti) he asked his ambassador in Siena for a full report of the hospital from its rector, Pietro di Nicolo Bolgarini. He specified the works of art, especially the now lost fresco of the birth of the Virgin over the facade by Ambrogio Lorenzetti and Simone Martini, and how once inside the hospital the sick, the poor, and the pilgrims would find "pulchros muros."

The two pilgrimage halls (one for men and one for women) were built about 1325 and enlarged periodically. In 1399 there were 130 beds for adults, and there were inpatients in these wards until 1983 (fig 1).

Giovanni Buzzichelli, the rector from 1433 to 1444 commissioned leading Sienese painters to decorate these halls to show the glorious past of this hospital and the good works then being performed. He knew both the hospitals and the art and culture of Florence, for example Domenico Veneziano's frescoes for Sant'Egidio, the church of the hospital of Santa Maria Nuova. Agostino di Marsiglio painted in gothic style the vaults of these halls - blue with stars and geometric patterns, saints, doctors of the church, patriarchs, and prophets. Four scenes on the left wall illustrate the history of the hospital and are balanced on the opposite wall by four scenes of contemporary charitable activities.

On the left wall Lorenzo di Pietro (Il Vecchietta) in 1441 painted the mythical foundation in 898; Domenico de Bartolo The Rector Enlarging the Hospital, Priamo della Quercia the Investiture of the Rector, and Domenico the Papal Bull of 1193. Domenico was also responsible for the four secular scenes on the right wall: Patient Care, Almsgiving, the Foundlings, and Feeding the Poor (figs 2-4). His innovative realism must have been as advanced in his day in Siena as were Ambrogio Lorenzetti's fresco cycles, Good and Bad Government, in the town hall of the previous century. An extra bay was added to the hall in the 1570s and was covered with two submannerist frescoes by Pietro d'Achille Crogi and Giovanni di Raffaelle Navesi, showing the payment of the foster parents in coin and with corn.

\section{Other artwork}

All institutional accounts in Siena had to be meticulous, and the hospital's books are, still in the city archives. Each annual account book was bound with a specially commissioned painted cover. The hospital chamberlain kept accounts of the income and expenses, and balance sheets were checked by the friars at the end of each month and read out before the warden and brothers. The hospital yearbooks, written by the secretary, also had cover paintings, such as of the treasurer receiving donations.

The hospital chapel of 1232-1446 has Vecchietta's large bronze statue, the Risen Christ. A Giovanni di Paolo altarpiece of St Catherine was dismantled in the eighteenth century, and the panels are scattered in museums in Europe and the United States. ${ }^{4}$ Behind the altar is Sebastiano Conca's Fesus Healing at the Pool of Bethesda of 1732, the same topic of miraculous care chosen by Hogarth three years later for the staircase at St Bartholomew's Hospital. ${ }^{9}$

Other artworks in the hospital have been dispersed $^{1}$ : few have any medical content. Some are in the Pinacoteca, among them Vecchietta's reliquary cabinet of 1445-9, an organ panel of $1447-50$ by Neroccio di Bartolomeo, and a 1444 lunette from the hospital reliquary's chapel of the patrons - the Pope and the Emperor-together with rector Buzzichelli and his wife. The cathedral has on its high altar a ciborium of 1467-72, once in the hospital chapel, and the cathedral museum has the wrought iron grille from the pilgrimage hall.

\section{The future}

The hospital was completely secularised in the eighteenth century, and then became part of the restructured university of 1886 as one of the leading Italian university hospitals. In 1990 the cathedral square no longer bustled with outpatients, ambulances, doctors, nurses, visitors, and patients. This cycle of activity all, after a thousand years, moved from the square into the new hospital in the suburbs. The old hospital is to be converted to a museum and will, for the first time, allow visitors to see these masterpieces of the Sienese quattrocento renaissance.

I am indebted to Professor $P$ Torriti for permission to use material from his book and to $\mathrm{Dr} A$ Manganelli for guiding me round the hospital. I thank Drs M Beal, G Bignardi, and C Lord for their help with the Italian.

1 Gallavotti Cavallero D. Lo spedale di Santa Maria della Scala in Siena. Vicenda di una committenza artistica. Pisa: Pacini Editore, 1985.

2 Torriti P. Il pellegrinaio nello spedale di Santa Maria della Scala a Siena. Siena: Lions Club, 1987.

3 Cotturi E. L'ospedale di S Maria della Scala di Siena. Ospedale d'Italic Chirurgia 1960;3:647-51.

4 Christiansen K, Kanter LB, Strehlke CB. Painting in renaissance Siena 1420-1500. New York: Metropolitan Museum of Art, 1989.

5 Wright HP. Statutes of the Hospital of the Holy Virgin Mary of Siena AD 1305 , translated from the Italian. London: Skeffington, 1880.

6 Banchi L. I rettori dello spedale di Santa Maria della Scala di Siena. Bologna: Fava e Garagnoni, 1877.

7 Michetti F. Provedimenti ospedalieri nel comune di Siena nel secolo XIII. Atti del XXI Congresso Internazionale di Storia della Medicine di Siena del 1968. Vol 1. Siena: Societa Internazionale di' Storia della Medicina, 1968:134-9.

8 Leverotti F. L'ospedale senese di Santa Maria della Scala in una relazione del 1456. Bulletino Senese di Storia Patria 1984;90:276-91. 9 Baron JH. Hogarth and hospitals. Lancet 1987;ii:1512-4. 